\title{
AME Surgical Journal: a journal that hopes to provoke surgeons' inspiration
}

Officially launched in May 2012, The Annals of Cardiothoracic Surgery (ACS) is the first AME journal that publishes primarily in the form of narrated surgical videos, which is strikingly well received by readers. However, as if a coin has its two sides, ACS experienced twists and turns in the course of Science Citation Index (SCI) application and it was not until June 20, 2019 that it finally obtained its first impact factor. Undeniably, never is the aim to launch a journal to get a place in the SCI list. Yet, SCI indexation and impact factors are of paramount importance in the development of a journal.

Now, we are going to launch a new journal-AME Surgical fournal (ASf). Why do I start this? What would be the goals and plans? How far will it go?... A bunch of questions pops into my head, yet there is only one answer to all these-I hope $A S f$ will become a journal that provokes surgeons' inspiration.

Surgeons are a group of adorably cute people. It's not hard to find their chats, even in social meetings, running on surgeries. They like commending and self-commending. For example, while commending a surgeon for being able to perform surgeries quickly, abruptly he might be criticized for not having fine enough skills. While another surgeon is commended for having meticulous skills, expectedly it will be followed by critiques like "he can't complete two surgeries in a day at this speed" or "the prognosis isn't necessarily good".

When I first came into contact with these surgeons, I had a lot of puzzles in my mind-it doesn't seem right to talk behind someone's back, does it? What made me more confused was that when I met both surgeons at the same time, they raised their glasses, cheered to each other and drank happily while addressing each other "brothers".

Until one day, I saw a surgeon walking calmly out of the operating room while having 4/5 of his surgical gown soaked in sweat. First, he assured the patient's family, “Today's surgery was a success. Don't worry!” But then he alerted his fellows, "Elevate level of care in the next $24 \mathrm{~h}$ and report to me instantly if seeing anything unusual." And only after that he explained to me, "Today's surgery was thrilling! Luckily everyone was well-trained." He then left to discuss the case with his team.

I was enlightened all in a sudden-the reason why surgeons have their unique style to comment on each other is that they need such "absolute confidence" to bravely manage and perform each surgery well.

Surgeons love learning. They like calling their teachers "masters". As what Qing Dynasty poet Zhenyu Luo said, "Once a teacher, always a father." Students should serve their teachers like their fathers. Not only do they have to learn from their teachers' knowledge and skills, but also their morals and spirits. Every young surgeon will strive to learn and become their master's right arm (the most important assistant). Apart from this, they also like to learn from others "under the table". On their desktop there are plenty of surgical videos downloaded, many of which from their masters, peers and even surgeons from another department. Unweariedly, they keep watching these videos over and over again in search of inspiration, as if they are practicing martial arts and almost get obsessed with it.

Surgeons are people with aspirations. Often is the growing path for surgeons very interesting: when they were young, their professors used to say, "If you want to become an excellent surgeon, you must first comprehend anatomy well." They, therefore, studied anatomy very hard. When they were having master's and $\mathrm{PhD}$ degrees, in order to acquire the knowledge and skills handed down directly from their masters, they did research seriously and wrote papers sedulously, hoping to become their master's right arm. Often do they go back and forth between basic research and clinical studies. To become an outstanding surgeon, they reminded themselves to "stay hungry and stay foolish", and not to fall into the tempting trap of basic research-which is usually thought to be closest to the "Nobel Prize", whereas clinical work is rather "mathematical" and far from that prize. After graduation and having stepped into the clinics, there came another "remedial phase"-they ran back over every version of anatomical charts from systemic to local anatomy, and "insanely" collected surgical videos of any kind. Whenever they unearthed a "raw footage" (uncut version of a surgical video), they drooled over them no matter how awkward they might look.

After years of training, there came the day when they were finally able to take charge of a particular surgery. Like skating on thin ice, each time they soaked their surgical gowns, but each time they confronted it courageously with that self-belief.

The Goddess of Luck always blesses diligent people. The day when they got promoted from a general surgeon to a 
director or professor, they started feeling like the "Nobel Prize" was quietly waving to them, lying somewhere perceivably out of reach.

Nevertheless, a successful operation does not imply a lifelong cure for patients-their conditions are ever-changing and some of them may have the chance of recurrence, which could make surgeons very helpless. Due to our limited knowledge of certain diseases like cancer, researchers need that "quiet moment" to ponder over the mechanism behind a disease—why does it occur? Why does it recur?

Becoming a director or professor is thus like a brand-new journey to them. It's their time to strengthen their "armies" and enlarge their research base to address all the unanswered questions. Even though they know better than anyone that the "Nobel Prize" is somehow too far-fetched, they will still devote themselves fully to their lifelong research without hesitation, as they realize saving patients' lives are the most invaluable thing they crave.

Here comes this group of cute, diligent and aspirational surgeons, to which ASf belong, for which ASf was born.

\section{Acknowledgments}

The author would like to thank Brad Li, Science Editor, AME Publishing Company for the translation of the article from Chinese into English.

Funding: None.

\section{Footnote}

Provenance and Peer Review: This article was commissioned by the editorial office, AME Surgical fournal. The article did not undergo external peer review.

Conflicts of Interest: The author has completed the ICMJE uniform disclosure form (available at https://asj.amegroups.com/ article/view/10.21037/asj.2019.09.01/coif). SDW serves as the Founder and CEO of AME Publishing Company (publisher of the journal). The author has no other conflicts of interest to declare.

Ethical Statement: The author is accountable for all aspects of the work in ensuring that questions related to the accuracy or integrity of any part of the work are appropriately investigated and resolved.

Open Access Statement: This is an Open Access article distributed in accordance with the Creative Commons AttributionNonCommercial-NoDerivs 4.0 International License (CC BY-NC-ND 4.0), which permits the non-commercial replication and distribution of the article with the strict proviso that no changes or edits are made and the original work is properly cited (including links to both the formal publication through the relevant DOI and the license). See: https://creativecommons.org/licenses/by-nc$\mathrm{nd} / 4.0 /$.

Stephen D. Wang
Founder and CEO, AME Publishing Company, Hong Kong, China.
(Email: swang@amegroups.com)

(Email: swang@amegroups.com)

doi: $10.21037 /$ asj.2019.09.01

View this article at: http://dx.doi.org/10.21037/asj.2019.09.01

doi: 10.21037/asj.2019.09.01

Cite this article as: Wang SD. AME Surgical fournal: a journal that hopes to provoke surgeons' inspiration. AME Surg J 2021;1:1. 